\title{
Sistem Informasi Islamic Character Building Pada SD IT Fathona
}

\author{
Rusmala Santi $^{1}$, Irfan Dwi Jaya ${ }^{2}$, Heevans Ridhwan Muhammad ${ }^{3}$ \\ rusmalasanti_uin@radenfatah.ac.id ${ }^{1}$, irfan_dj@radenfatah.ac.id ${ }^{2}$, heevansrm@gmail.com ${ }^{3}$ \\ ${ }^{1}$ Prodi Sistem Informasi, Fakultas Sains dan Teknologi, UIN Raden Fatah Palembang \\ ${ }^{2}$ Prodi Sistem Informasi, Fakultas Sains dan Teknologi, UIN Raden Fatah Palembang \\ ${ }^{3}$ Prodi Sistem Informasi, Fakultas Sains dan Teknologi, UIN Raden Fatah Palembang
}

Diterima: 15 Juli 2019 | Direvisi: 27 Agustus 2019|Disetujui: 11 Oktober 2019

(C) 2019 Program Studi Sistem Informasi Fakultas Sains dan Teknologi,

Universitas Islam Negeri Raden Fatah Palembang, Indonesia

\begin{abstract}
Abstrak: Islamic Character Building merupakan salah satu program dari SD IT Fathona yang bertujuan untuk membangun karakter Islami pada siswa. Program tersebut memiliki proses penilaian dengan menggunakan buku mutaba'ah. Penggunaan buku mutaba'ah memiliki beberapa permasalahan seperti sulitnya bekerja sama dengan orang tua murid, murid sering berbohong dalam mengisi buku mutaba'ah, dan seringnya terjadi kehilangan atau kerusakan pada buku mutaba'ah. Dibangunnya sistem informasi Islamic Character Building untuk dapat menghilangkan atau mengurangi permasalahan yang terjadi. Sistem informasi Islamic Character Building dibangun dalam dua platform yaitu android dan web. Sistem informasi Islamic Character Building dibangun dengan pendekatan mobile-D yang menjadikan proses pembangunannya lebih rapi, terstruktur, dan terperinci. Sistem Informasi Islamic Character Building ini dapat membantu kegiatan program Islamic Character Building.
\end{abstract}

Kata Kunci: Islamic Character Building, Sistem Informasi, mobile-D

Abstract: Islamic Character Building is a program from SD IT Fathona that aims to build Islamic character in students. The program has an assessment process using the book mutaba'ah. The use of the mutaba'ah book has several problems such as the difficulty of working with parents, students often lie in filling the mutaba'ah book, and often there is loss or damage to the mutaba'ah book. Development of an Islamic Character Building information system to be able to eliminate or reduce problems that occur. The Islamic Character Building information system is built on two platforms namely android and the web. The Islamic Character Building information system was built with a mobile-D approach that made the development process neater, structured, and detailed. This Islamic Character Building Information System can help with Islamic Character Building programs.

Keywords: Islamic Character Building, Information System, mobile-D

\section{PENDAHULUAN}

Pendidikan karakter merupakan bentuk kegiatan manusia yang di dalamnya terdapat suatu tindakan yang mendidik diperuntukkan bagi generasi selanjutnya. Tujuan Pendidikan karakter adalah untuk membentuk penyempurnaan diri individu secara terus menerus dan melatih kemampuan diri demi menuju kearah hidup yang lebih baik.

Sekolah Dasar Islam Terpadu Fathona adalah salah satu sekolah yang mempunyai program khusus untuk pengembangan karakter pada siswa. Islamic Character Building (ICB) adalah salah satu program SD IT Fathona. Membangun karakter Islam pada siswa. ICB berfokus untuk membimbing siswa untuk mengetahui bagaimana akhlak seorang muslim, bagaimana menjadi anak soleh, juga untuk memperdalam ilmu agama.

Program ICB diterapkan mulai dari siswa kelas satu sampai kelas enam. Materi pengembangan karakter diberikan kepada siswa setiap satu bulan sekali di mana materi dari 
siswa kelas satu sampai kelas enam sama namun dalam tiap bulan memiliki fokus tema yang berbeda-beda. Materi yang akan diberikan selama satu tahun ajaran sudah ditetapkan di awal tahun dalam rapat kerja, tinggal guru masing-masing menyampaikan kepada siswa dengan cara yang berbeda-beda. Program ICB memiliki satu koordinator dan beberapa guru pengajar yang ditetapkan sesuai kurikulum.

Namun, dalam prakteknya program ini pernah mengalami beberapa hambatan atau masalah, seperti beberapa orang tua yang menuntut banyak namun susah untuk diajak bekerja sama dengan alasan sibuk. Ada pula siswa yang berbohong dalam mengisi buku laporan di mana yang harusnya diisi oleh orang tua namun siswa mengisinya sendiri. Ada juga masalah berupa hilang atau rusaknya buku laporan mutaba'ah.

Berdasarkan penjelasan tentang program ICB serta beberapa hambatan atau masalah yang pernah terjadi, maka akan dilakukan penelitian untuk lebih memaksimalkan program yang sudah ada serta mengurangi masalah yang terjadi dengan judul "Sistem Informasi Islamic Character Building pada SD IT Fathona".

\section{METODOLOGI PENELITIAN}

\subsection{Metode Pengumpulan Data}

Metode pengumpulan data yang digunakan dalam membangun Sistem Informasi Islamic Character Building pada SD IT Fathona adalah:

1. Studi Pustaka.

Pada penelitian ini, dilakukan studi pustaka dengan membaca buku dan jurnal untuk mencari referensi-referensi yang dapat membantu dalam proses penelitian.

\section{Wawancara.}

Menurut (Martono, 2015), wawancara merupakan metode pengumpulan data dengan cara peneliti mengajukan pertanyaan secara lisan kepada seseorang. Sedangkan, Observasi merupakan teknik mendapatkan data dengan cara mengamati langsung objek datanya (Jogiyanto, 2008).

Pada penelitian ini, wawancara dilakukan untuk mengumpulkan informasi-informasi penting terkait sistem yang akan dibangun dari orang-orang yang berkepentingan dalam program Islamic Character Building.

\subsection{Metode Pengembangan Sistem}

Metode pengembangan sistem yang digunakan adalah pendekatan Mobile-D. Penggunaan pendekatan Mobile-D pada penelitian ini dilandaskan oleh jurnal penelitian yang dilakukan oleh (Abrahamsson, Hanhineva, Hulkko, Ihme, \& Jäälinoja, 2004) yang mengatakan bahwa pendekatan ini diciptakan khusus untuk pengembangan sistem berbasis mobile. Mobile-D memiliki 5 (lima) fase pengembangan, yaitu explore, initialize, productionize, stabilize, dan system test \& fix. Pada masing-masing fase juga memiliki beberapa tahap pengembangan yang harus dilakukan.

Pada fase pertama, explore, ada tiga tahap yang akan dilewati, yaitu stakeholder establishment, scope definition, dan project establishment. Pada fase ini secara umum akan melakukan pembentukan dan penentuan pihak-pihak apa saja yang terlibat dalam suatu proyek, mendefinisikan ruang lingkup proyek serta waktu pengerjaan proyek yang disetujui oleh setiap pihak yang terlibat, dan mempersiapkan semua sumber daya yang dibutuhkan, mulai dari bahan atau alat yang dibutuhkan hingga manusianya sendiri (VTT Electronics).

Pada fase kedua, initialize, ada empat tahap yang dilakukan, yaitu project set-up, planning day, working day, dan release day. Fase ini merupakan fase untuk mendapatkan pemahaman terhadap proyek yang akan dibuat, membuat deskripsi arsitektur, rencana arsitektur, dan melakukan pemeriksaan terhadap masalah dalam pengembangan dan memecahkannya (VTT Electronics). 
Pada fase ketiga, productionize, tahap yang akan dilalui adalah planning day, working day, dan release day. Pada fase ini pengembang mulai mengimplementasikan fungsi utama sistem yang akan dibuat berdasarkan perancangan yang sudah dibuat pada fase sebelumnya. Fase ini hanya berfokus pada fungsi utama dari sistem yang akan dibuat (VTT Electronics).

Di fase keempat, stabilize, tahap yang akan dilalui adalah planning day, working day documentation wrap-up, dan release day. Pada fase ini dilakukan penyelesaian implementasi fitur-fitur pelengkap pada sistem yang akan dibuat. Fase ini juga bertujuan yang meningkatkan dan memastikan kualitas produk (VTT Electronics).

Pada fase kelima, system test \& fix, tahap yang akan dilalui adalah system test, planning day, working day, dan release day. Di fase ini dilakukan pengujian terhadap proyek yang telah jadi untuk mencari tahu apakah proyek sudah berjalan sesuai keinginan, apakah semua fungsi berjalan dengan baik, dan mengetahui apakah ada kesalahan yang terjadi agar dapat diperbaiki (VTT Electronics).

\section{HASIL DAN PEMBAHASAN}

\subsection{Tahap Explore}

Pada bagian ini dilakukan beberapa tahapan yang terbagi-bagi menjadi beberapa subbab, antara lain:

\subsubsection{Stockholder Establishment}

Pada penelitian ini, pihak-pihak yang terlibat yaitu:

a. Kepala Sekolah.

b. Koordinator $I C B$.

c. Wali Kelas.

d. Wali Murid.

\subsubsection{Scope Definition}

Ruang lingkup dalam proyek ini adalah menganalisis permasalahan dan kebutuhan dalam pembangunan sistem informasi Islamic Character Building, menggambarkan alur proses sistem menggunakan flowchart, melakukan pemodelan proses sistem menggunakan $U M L$, melakukan pemodelan data menggunakan ERD, mengimplementasikan hasil perancangan dengan membangun sistem informasi yang utuh berdasarkan perancangan sebelumnya, menguji kelayakan dan kualitas sistem informasi untuk mendeteksi kesalahan dan kekurangan yang ada menggunakan Teknik Boundary Value Analysis dari black box testing.

\subsubsection{Project Establishment}

\section{a) Pemodelan Proses}

Alat pemodelan proses yang digunakan untuk membangun Sistem Informasi Islamic Character Building pada SD IT Fathona ini adalah unified modeling language (UML). Diagram $U M L$ yang digunakan terdiri dari use case diagram untuk pemodelan perilaku sistem, activity diagram untuk pemodelan aliran kerja, dan class diagram untuk pemodelan struktur diagram.

\section{b) Pemodelan Perilaku Sistem}

Pemodelan perilaku sistem dibuat menggunakan use case diagram. Use case diagram Sistem Informasi Islamic Character Building pada SD IT Fathona yang dibangun terdiri dari 4 (empat) aktor dan memiliki hak akses masing-masing.

Aktor wali murid memiliki hak akses berupa menginput nilai anaknya, melihat nilai anaknya, mengirim pesan, melihat berita dan melihat materi setelah melakukan proses login sebelumnya.

Aktor wali kelas memiliki hak akses berupa melihat nilai seluruh siswa pada kelasnya, mengirim pesan, melihat berita, dan melihat materi setelah melakukan proses login sebelumnya. 
Aktor koordinator memiliki hak akses berupa melihat informasi yang dihasilkan, melihat nilai seluruh siswa pada SD IT Fathona, mengelola materi, mengelola berita, mengelola data siswa, mengelola data pengajar, mengelola data kelas, dan mengelola data Amaliyah (data mengenai amal) setelah melakukan login sebelumnya.

Aktor Kepala Sekolah memiliki hak akses berupa melihat informasi yang dihasilkan, melihat, berkomentar, serta memvalidasi berita, dan melihat, berkomentar, serta memvalidasi materi setelah melakukan login sebelumnya.

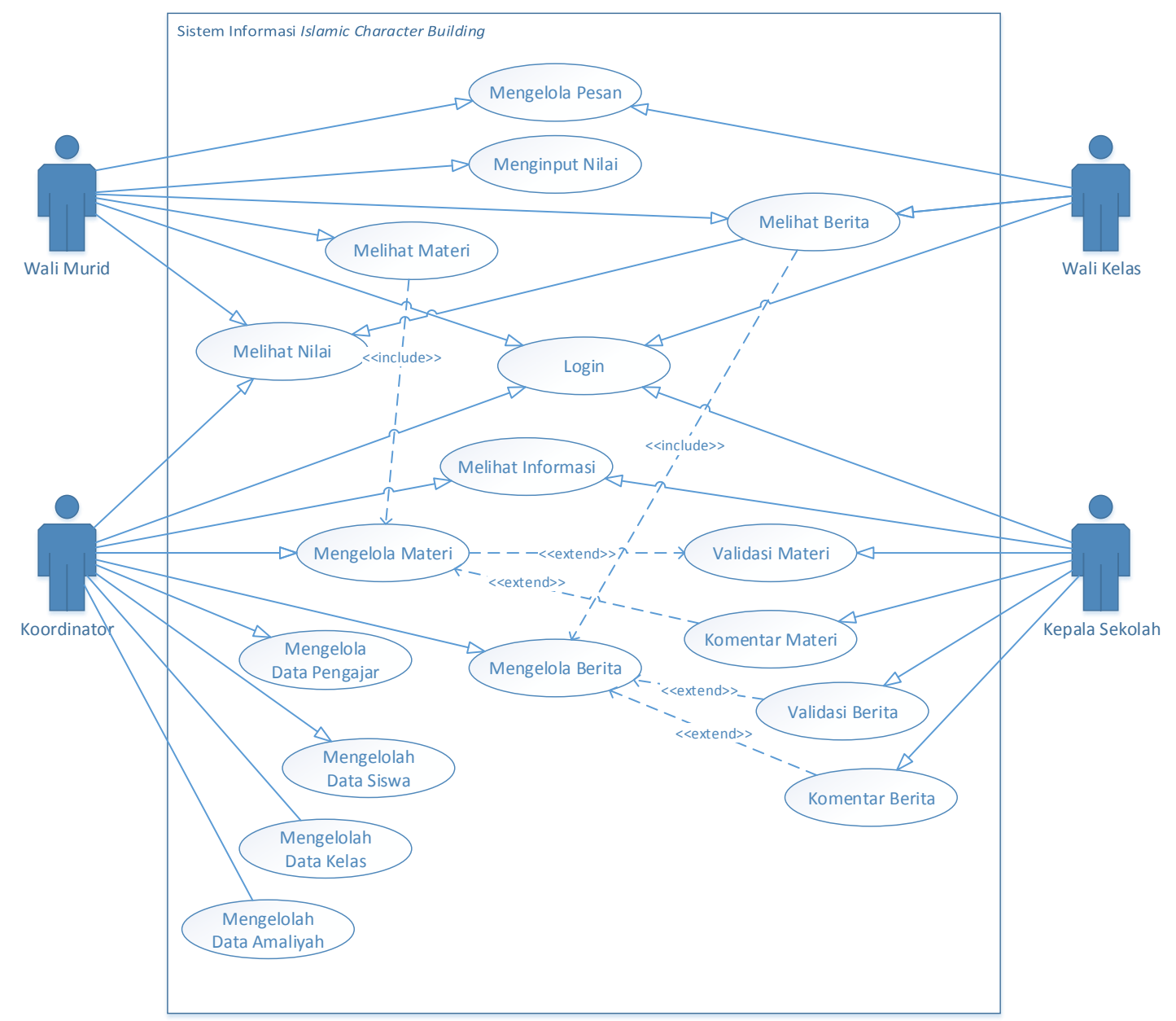

Gambar 1. Use Case Diagram Sistem Informasi Islamic Character Building

\section{c) Pemodelan Struktur Sistem}

Pemodelan struktur sistem dibuat menggunakan class diagram. Class diagram menggambarkan struktur sistem dari segi pendefinisian kelas-kelas yang akan dibuat untuk membangun sistem. Class diagram yang dibangun ini terdiri dari Class Berita, Class Materi, Class Kelas, Class Pengajar, Class Auth, Class Pesan, Class Siswa, Class Nilai, dan Class Amaliyah. 


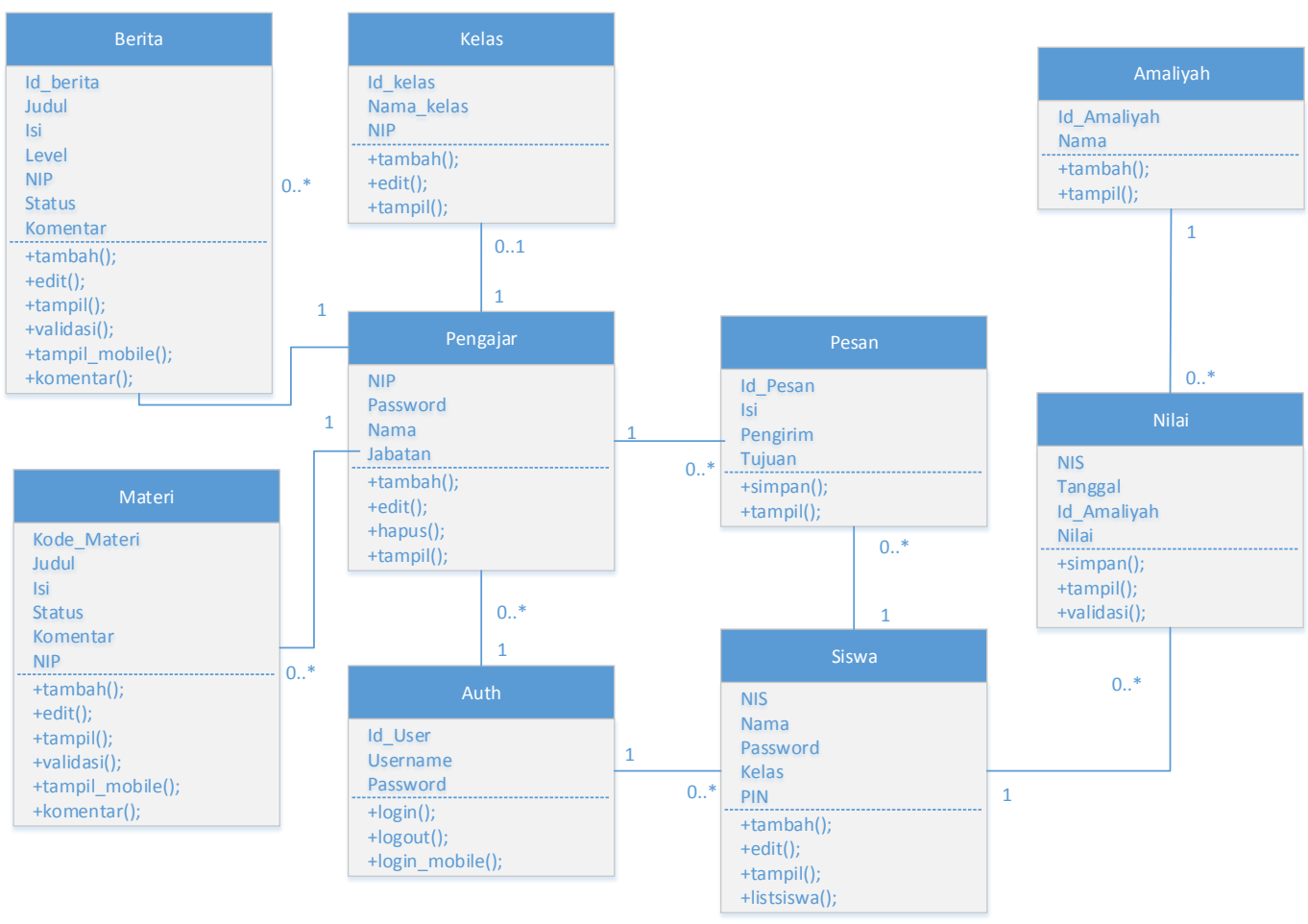

Gambar 2. Class Diagram Sistem Informasi Islamic Character Building

\subsection{Initialize}

Pada bagian ini dilakukan beberapa tahapan yang terbagi-bagi menjadi beberapa subbab, antara lain:

\subsubsection{Planning Day}

\section{a) Perancangan Tabel}

\section{Tabel Pengajar}

Tabel pengajar terdiri dari 4 (emapat) field dengan NIP sebagai primary key. Struktur tabel dapat dilihat pada Tabel 1.

Tabel 1. Tabel Pengajar

\begin{tabular}{ccccc}
\hline No. & Field & Type & Size & Keterangan \\
\hline 1. & NIP & Int & 10 & Primary Key \\
2. & Nama & Varchar & 30 & Nama Pegawai \\
3. & Password & Varchar & 20 & Password Pengajar \\
4. & Jabatan & Varchar & 15 & Jabatan Pegawai \\
\hline
\end{tabular}

\section{Tabel Siswa}

Tabel siswa terdiri dari 5 (lima) field dengan NIS sebagai primary key. Struktur tabel dapat dilihat pada Tabel 2 .

Tabel 2. Tabel Siswa

\begin{tabular}{ccccc}
\hline No. & Field & Type & Size & Keterangan \\
\hline 1. & NIS & Int & 10 & Primary Key \\
2. & Nama & Varchar & 30 & Nama Siswa \\
3. & Password & Varchar & 20 & Password Siswa \\
4. & Kelas & Varchar & 2 & Kelas Siswa \\
& & & & \\
\hline
\end{tabular}


56 |JUSIFO (Jurnal Sistem Informasi), p-ISSN: 2460-092X, e-ISSN: 2623-1662

\begin{tabular}{ccccc}
\hline & & & & \\
\hline No. & Field & Type & Size & Keterangan \\
\hline 5. & PIN & Int & 10 & PIN Konfirmasi \\
\hline
\end{tabular}

\section{Tabel Kelas}

Tabel kelas terdiri dari 3 (tiga) field dengan Id_Kelas sebagai primary key. Struktur tabel dapat dilihat pada Tabel 3.

Tabel 3. Tabel Kelas

\begin{tabular}{ccccc}
\hline No. & Field & Type & Size & Keterangan \\
\hline 1. & Id_Kelas & Int & 2 & Primary Key \\
2. & Nama_Kelas & Varchar & 2 & Nama Kelas \\
3. & NIP & Int & 10 & NIP Wali Kelas \\
\hline
\end{tabular}

Tabel Amaliyah

Tabel amaliyah terdiri dari 2 (dua) field dengan Id_Amaliyah sebagai primary key. Struktur tabel dapat dilihat pada Tabel 4.

Tabel 4. Tabel Amaliyah

\begin{tabular}{ccccc}
\hline No. & Field & Type & Size & Keterangan \\
\hline 1. & Id_Amaliyah & Int & 2 & Primary Key \\
2. & Nama & Varchar & 25 & Nama Amaliyah \\
\hline
\end{tabular}

Tabel Nilai

Tabel nilai terdiri dari 4 (empat) field. Struktur tabel dapat dilihat pada Tabel 5.

Tabel 5. Tabel Nilai

\begin{tabular}{ccccc}
\hline No. & Field & Type & Size & Keterangan \\
\hline 1. & NIS & Int & 10 & NIS Siswa \\
2. & Id_Amaliyah & Varchar & 2 & Id Amaliyah \\
3. & Tanggal & Date & & Tanggal \\
4. & Nilai & Int & 2 & Nilai Siswa \\
\hline
\end{tabular}

Tabel Materi

Tabel materi terdiri dari 6 (enam) field dengan Kode_Materi sebagai primary key. Struktur tabel dapat dilihat pada Tabel 6.

Tabel 6. Tabel Materi

\begin{tabular}{ccccc}
\hline No. & Field & Type & Size & Keterangan \\
\hline 1. & Kode_Materi & Varchar & 6 & Primary Key \\
2. & Judul & Varchar & 20 & Judul Materi \\
3. & Isi & Text & & Isi Materi \\
4. & Status & Varchar & 15 & Status Materi \\
5. & Komentar & Text & & Komentar Materi \\
6. & NIP & Int & 10 & NIP Pengajar \\
\hline
\end{tabular}

Tabel Berita

Tabel berita terdiri dari 7 (tujuh) field dengan Id_berita sebagai primary key. Struktur tabel dapat dilihat pada Tabel 7.

Tabel 7. Tabel Berita

\begin{tabular}{ccccc}
\hline No. & Field & Type & Size & Keterangan \\
\hline 1. & Id_berita & Int & 6 & Primary Key
\end{tabular}




\begin{tabular}{ccccc}
\hline & & & & \\
\hline No. & Field & Type & Size & Keterangan \\
\hline 2. & Judul & Varchar & 20 & Judul Berita \\
3. & Isi & Text & & Isi Berita \\
4. & Level & Int & 1 & Level Berita \\
5. & NIP & Int & 10 & NIP Pengajar \\
6. & Status & Varchar & 15 & Status Berita \\
7. & Komentar & Text & & Komentar Berita \\
\hline
\end{tabular}

\section{Tabel Pesan}

Tabel pesan terdiri dari 4 (empat) field dengan Id_Pesan sebagai primary key. Struktur tabel dapat dilihat pada Tabel 8.

Tabel 8. Tabel Pesan

\begin{tabular}{ccccc}
\hline No. & Field & Type & Size & Keterangan \\
\hline 1. & Id_Pesan & Int & 10 & Primary Key \\
2. & Isi & Text & & Isi Pesan \\
3. & Pengirim & Varchar & 50 & Pengirim \\
4. & Tujuan & Varchar & 50 & Tujuan \\
\hline
\end{tabular}

\subsubsection{Working Day}

Pada tahap working day, dilakukan pengecekan dan uji coba terhadap sumber daya teknik sebelum dilakukan pengimplementasian terhadap hasil perancangan. Hasil dari pengecekan ini sebagai berikut:

1) Framework Ionic versi 4.1.2 yang akan digunakan untuk pembangunan proyek versi android berhasil di-install dan dapat dijalankan dengan baik.

2) Framework CodeIgniter versi 3.1.7 yang akan digunakan untuk pembangunan proyek versi web berhasil di-install dan dapat dijalankan dengan baik.

3) Xатрp versi 5.6.37-1 yang akan digunakan untuk pengolahan database berhasil di-install dan dapat dijalankan dengan baik.

\subsection{Productionize}

Pada bagian ini dilakukan beberapa tahapan yang terbagi-bagi menjadi beberapa subbab, antara lain:

\subsubsection{Planning Day}

Maka, yang akan dikerjakan pada tahap ini adalah:

a) Fitur input nilai dari wali murid.

b) Fitur lihat nilai bagi wali murid, wali kelas, dan koordinator.

\subsubsection{Release Day}

Tujuan dari tahap ini untuk merilis sistem yang sepenuhnya bekerja selama pengembangan. Maka, pada fase ini berisi beberapa laporan sebagai berikut:

a) Fitur yang dikembangkan bekerja dengan baik.

b) Semua fitur yang direncanakan berhasil dikembangkan atau diimplementasikan.

\subsection{Stabilize}

Pada bagian ini dilakukan beberapa tahapan yang terbagi-bagi menjadi beberapa subbab, antara lain:

\subsubsection{Planning Day}

Tahap ini bertujuan untuk memilih dan merencanakan apa yang akan dikerjakan pada fase stabilize. Setelah diimplementasikan fitur utama pada Sistem Informasi Islamic Character 
Building, maka akan ditambah fitur-fitur pelengkap untuk menambah kualitas sistem. Maka, yang akan dikerjakan pada tahap ini adalah:

a) Fitur login untuk wali murid, wali kelas, koordinator, dan kepala sekolah.

b) Fitur membaca materi untuk wali murid dan wali kelas.

c) Fitur membaca berita untuk wali murid dan wali kelas.

d) Fitur mengirim pesan untuk wali murid dan wali kelas.

e) Fitur mengelola berita, materi, data siswa, data pengajar, data kelas, dan data amaliyah untuk koordinator.

f) Fitur memvalidasi berita dan materi untuk kepala sekolah.

g) Fitur melihat informasi untuk koordinator dan kepala sekolah.

\subsubsection{Release Day}

Tujuan dari tahap ini untuk merilis sistem yang sepenuhnya bekerja selama pengembangan. Maka, pada tahap ini berisi beberapa laporan sebagai berikut:

a) Fitur yang dikembangkan bekerja dengan baik.

b) Semua fitur yang direncanakan berhasil untuk diimplementasikan.

c) Sistem informasi Islamic Character Building berhasil dibangun dengan semua fitur yang ada bekerja dengan baik.

\subsection{System Test and Fix}

Pada bagian ini dilakukan beberapa tahapan yang terbagi-bagi menjadi beberapa subbab, antara lain:

\subsubsection{System Test}

\section{a) Pengujian Awal}

Pengujian ini dilakukan oleh pengembang dengan Teknik Boundary Value Analysis dari blackbox testing. Hasilnya menunjukkan tidak ditemukan kesalahan ataupun kegagalan sistem berdasarkan tabel hasil pengujian.

b) Pengujian Akhir

Pengujian ini dilakukan dengan mempresentasikan sistem yang sudah dibangun di depan pelanggan dan meminta masukan atas sistem tersebut. Hasil pengujian akhir ini adalah:

1) Untuk sistem web, sudah baik dan cukup.

2) Untuk sistem android, harus ditambah fitur melihat rekapitulasi nilai untuk wali murid.

\subsection{System Fix}

Pada bagian ini dilakukan beberapa tahapan yang terbagi-bagi menjadi beberapa subbab, antara lain:

\subsubsection{Planning Day}

Tahap ini bertujuan untuk memilih dan merencanakan apa yang akan dikerjakan pada tahap system fix. Berdasarkan hasil pengujian sebelumnya, maka yang akan dikerjakan pada tahap ini adalah fitur melihat rekapitulasi nilai untuk wali murid.

\subsubsection{Release Day}

Tujuan dari tahap ini untuk merilis sistem yang sepenuhnya bekerja selama pengembangan. Maka, pada fase ini berisi beberapa laporan sebagai berikut.

1) Fitur yang dikembangkan bekerja dengan baik.

2) Semua fitur yang direncanakan berhasil dikembangkan atau diimplementasikan.

3) Kesalahan atau kecacatan atau kekurangan yang didapatkan pada system test sudah berhasil diperbaiki.

4) Sistem Informasi Islamic Character Building berhasil dibangun dengan semua fitur yang sudah ada dan yang baru bekerja dengan baik. 
5) Pihak pelanggan yaitu SD IT Fathona menyatakan sudah merasa cukup dengan sistem yang sudah dibangun.

\section{KESIMPULAN} berikut:

Berdasarkan hasil penelitian pada penelitian ini, maka didapatkan kesimpulan sebagai

1) Dengan Sistem Informasi Islamic Character Building, orang tua dapat mengisi nilai praktik anaknya kapan saja dan di mana saja dengan menggunakan perangkat telepon genggam pribadinya, tanpa perlu menggunakan buku mutaba'ah. Guru juga dapat melihat dan memantau nilai anak muridnya dengan menggunakan perangkat telepon genggam pribadinya. Sehingga Sistem Informasi Islamic Character Building dapat memudahkan orang tua dan guru dalam pengisian buku mutaba'ah.

2) Dengan Sistem Informasi Islamic Character Building, pihak sekolah dapat memperoleh informasi yang lebih banyak dari sebelumnya. Juga dengan otomatis menghasilkan rekapitulasi nilai masing-masing siswa sehingga mengurangi pekerjaan koordinator. Orang tua juga mendapatkan informasi berupa rekapitulasi nilai anaknya yang sebelumnya tidak didapatkan. Sehingga Sistem Informasi Islamic Character Building dapat membantu pihak sekolah dan orang tua dalam memanfaatkan buku mutaba'ah.

3) Dengan Sistem Informasi Islamic Character Building, pihak sekolah tidak perlu lagi menyediakan buku mutaba'ah, orang tua dan guru dapat berkomunikasi jarak jauh, pihak sekolah mendapatkan informasi yang lebih banyak. Memudahkan koordinator dalam mendapatkan rekapitulasi nilai. Sehingga Sistem Informasi Islamic Character Building dapat membantu kegiatan program Islamic Character Building.

\section{DAFTAR RUJUKAN}

Abrahamsson, P., Hanhineva, A., Hulkko, H., Ihme, T., \& Jälinoja, J. (2004). Mobile-D: An Agile Approach for Mobile Application Development. OOPSLA, 174-175.

Jogiyanto. (2008). Metodologi Penelitian Sistem Informasi. Yogyakarta: Andi.

Martono, N. (2015). Metode Penelitian Sosial. Jakarta: PT. Rajagrafindo Persada. 
60 | JUSIFO (Jurnal Sistem Informasi), p-ISSN: 2460-092X, e-ISSN: 2623-1662 